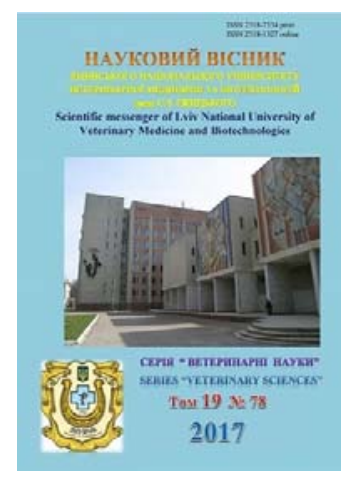

Науковий вісник Львівського національного університету ветеринарної медицини та біотехнологій імені С.З. Гжицького

Scientific Messenger of Lviv National University of Veterinary Medicine and Biotechnologies

doi:10.15421/nvlvet7822

ISSN 2518-7554 print

ISSN 2518-1327 online

$\underline{\text { http://nvlvet.com.ua/ }}$

УДК 574.2:619:619.98

\title{
Екологічні особливості епізоотичних процесів
}

\author{
Б.М. Куртяк, М.С. Романович, Т.О. Пундяк, М.М. Романович, Л.В. Романович, Г.В. Собко \\ kurtakbohdan@gmail.com,r.m.s.@ukr.net, to-pundyak@i.ua,romanovichmm@gmail.com \\ romanovichluda@gmail.com,sobko2312@gmail.com
}

Львівський національний університет ветеринарної медицини та біотехнологій імені С.3. Гжицького, вул. Пекарська, 50, м. Львів, 79010, Україна

\begin{abstract}
У виникненні, розвитку і перебігу епізоотій часто не враховують екологічних особливостей як збудників інфекиійних захворювань - стійкість у зовнішньому середовищі, діапазон, адаптаиії до різних видів тварин, так і переносників та резервуару збудників. Епізоотологія, вивчаючи екологічні взаємозв'язки тварин, розкриває закономірності прогнозування епізоотій, з'ясування яких має суттєве значення для складання плану протиепізоотичних заходів. Раціональний план заходів, розроблений на основі обтрунтованого прогнозу, забезпечує його ефективність.

Епізоотологічна географія, яка вивчає поширення заразних хвороб тварин в різних природно-географічних умовах, дозволяє розкрити значення тих чи інших зовнішніх факторів. Крім того, за ї̈ допомогою можна не тільки описати територію поширення тих чи інших інфекиійних хвороб, а й пояснити географію захворювань, історію їх виникнення і розвитку. Відтак можна скласти прогностичні карти, за якими виявляють райони зі сприятливими і несприятливими умовами для поширення захворювань і дають прогнозування деяких епізоотій, що виявляються сезонно або через певну кількість років. Значна кількість інфекиійних хвороб є антропозоонозами, а ареали їх розповсюдження пов'язані з фізико-географічними зонами, в яких історично склалися природні осередки.

Вивчення епізоотології, з точки зору екології, збагачує пізнання епізоотологічних закономірностей. Екологія тварин вивчає взаємовідношення живих організмів, спосіб їхнього життя в зв'язку з умовами існування в навколишньому середовищі, динаміку чисельності видів і особливість біоченозів.

Ключові слова: епізоотологія, епізоотія, екологія, інфекційна хвороба, інфекційний процес, збудник захворювання, вогнище інфекиї̈, джерело збудника інфекиії.
\end{abstract}

\section{Экологические особенности эпизоотических прцессов}

Б.М. Куртяк, Н.С. Романович, Т.А. Пундяк, Н.Н. Романович, Л.В. Романович, Г.В. Собко kurtakbohdan@gmail.com, r.m.s.@ukr.net, to-pundyak@i.ua, romanovichmm@gmail.com romanovichluda@gmail.com, sobko $2312 @$ gmail.com

Львовский национальный университет ветеринарной медицины и биотехнологий имени С.3. Гжицкого, ул. Пекарская, 50, г. Львов, 79010, Украина

В возникновении, развитии и течении эпизоотий часто не учитывают экологических особенностей как возбудителей инфекционных заболеваний - устойчивость во внешней среде, диапазон, адаптации к различным видам животных, так $и$ переносчиков и резервуара возбудителей. Эпизоотология, изучая экологические взаимосвязи животных, раскрывает закономерности прогнозирования эпизоотий, выяснение которых имеет существенное значение для составления плана противоэпизоотических мероприятий. Рациональный план мероприятий, разработанный на основе обоснованного прогноза, обеспечивает его эффективность.

Эпизоотологическая география, изучающая распространение заразных болезней животных в различных природногеографических условиях, позволяет раскрыть значение тех или иных внешних факторов. Кроме того, с ее помощью можно не только описать территорию распространения тех или иных инфекиионных болезней, но и объяснить географию

Citation:

Kurtyak, B.M., Romanovych, M.S., Pundyak, T.O., Romanovych, M.M., Romanovych, L.V., Sobko, G.V. (2017). Ecological features of episotic processes. Scientific Messenger LNUVMB, 19(78), 108-111. 
заболеваний, историю их возникновения и развития. В результате этого можно составить прогностические карты, по которым выявляют районы с благоприятными и неблагоприятными условиями для распространения заболеваний и дают прогнозирования некоторых эпизоотий, которые проявляются сезонно или через определенное количество лет. Значительное количество инфекичонных болезней являются антропозоонозами, а ареаль их распространения связаны с физикогеографическими зонами, в которых исторически сложились природные очаги.

Изучение эпизоотологии, с точки зрения экологии, обогащуает познание эпизоотологических закономерностей. Экология животных изучает взаимоотношения живых организмов, образ их жизни в связи с условиями существования в окружающей среде, динамику численности видов и особенность биоченозов.

Ключевые слова: эпизоотология, эпизоотия, экология, инфекичонная болезнь, инфекционный процесс, возбудитель заболевания, очаг инфекции, источник возбудителя инфекции.

\title{
Ecological features of episotic processes
}

\author{
B.M. Kurtyak, M.S. Romanovych, T.O. Pundyak, M.M. Romanovych, L.V. Romanovych, G.V. Sobko \\ kurtakbohdan@gmail.com,r.m.s.@ukr.net, to-pundyak@i.ua,romanovichmm@gmail.com \\ romanovichluda@gmail.com, sobko2312@gmail.com
}

\section{Stepan Gzhytskyi National University of Veterinary Medicine and Biotechnologies Lviv, Pekarska Str., 50, Lviv, 79010, Ukraine}

In the emergence, development and flow of epizootics, environmental features are often not taken into account as causative agents of infectious diseases - stability in the external environment, range, adaptation to different types of animals, and vectors and reservoir of pathogens. Epizootology, studying the ecological interrelations of animals, reveals the patterns of prediction of epizootics, the elucidation of which is essential for the development of a plan for antiepizootic measures. A rational plan of measures, developed on the basis of an informed forecast, ensures its effectiveness.

Epizootological geography, which studies the spread of infectious animal diseases in various natural and geographical conditions, allows us to disclose the significance of various external factors. In addition, with its help you can not only describe the territory of the spread of various infectious diseases, but also explain the geography of diseases, the history of their origin and development. As a result, it is possible to draw up prognostic maps that identify areas with favorable and unfavorable conditions for the spread of diseases and give predictions of some epizootics that occur seasonally or after a certain number of years. A significant number of infectious diseases are anthropozoonoses, and the areas of their spread are associated with physical and geographical zones in which natural foci are historically formed.

The study of epizootology, from the point of view of ecology, enriches the knowledge of epizootological regularities. The ecology of animals studies the interrelationships of living organisms, the way of their life in connection with the conditions of existence in the environment, the dynamics of the number of species and the peculiarity of biocenoses.

Key words: epizootology, epizootics, ecology, infectious disease, infectious process, causative agent of the disease, the focus of infection, the source of the causative agent of infection.

\section{Вступ}

Екологія тварин вивчає взаємовідносини живих організмів, спосіб їхнього життя у зв'язку з умовами існування в навколишньому середовищі, динаміку чисельності видів і особливість біоценозів. Вивчення епізоотології, з точки зору екології, збагачує пізнання епізоотологічних закономірностей (Naumov, 1963).

Екологічні особливості в епізоотології - це розділ, який вивчає взаємовідносини збудників інфекційних захворювань 3 урахуванням екологічних зв'язків, переносників і сприйнятливих тварин у взаємозв'язку 3 умовами зовнішнього середовища епізоотичного вогнища, він вивчає міжвидові зв'язки тварин, епізоотологічну активність членистоногих, міграцію тварин і птиці та ін. (Naumov, 1963; Pljashhenko and Sidorov, 1978).

Відомий еколог Б.Г. Іоганзен відзначав, що сьогодні жодна біологічна дисципліна не може успішно розвиватися в ізоляції від екології. Завдання полягає не в тому, щоби відмежувати їх від екології, але, навпаки, всіляко пронизати їх духом екології, бо не можна розглядати організм поза єдністю $з$ умовами його життя.

В останні роки такі науки, як морфологія, фізіологія, радіологія, геохімія, протозоологія, гельмінтологія та ін., використовують досягнення екології. Академік К.І. Скрябін відзначав, що роботи у напрямку гельмінтології дозволили нам підійти до вивчення спільноти гельмінтів, зауважити закономірну зональність у розповсюдженні їх в тих чи інших органах господаря, відкрити тим самим сторінку в нашій науці - гельмінтоценологіi. Ці роботи збагатили загальну біологію та паразитологію цілою низкою цікавих висновків і узагальнень. В.В. Ковальський називав розділ геохімії геохімічною екологією, розуміючи під цим науку, що вивчає взаємовідносини організмів 3 геохімічним середовищем. Близьким до цього є визначення розділу науки, яку А.А. Передельский називав радіоекологією (Bisiuk, 2012).

Вчення про природні вогнища трансмісивних хвороб дало можливість розкрити складні взаємини збудника, переносників і резервуару (носіїв збудників захворювання) між собою і навколишнім зовнішнім середовищем.

Великий інтерес становлять дослідження 3 еколого-епізоотологічної адаптації патогенних мікроорганізмів до умов існування, утворення внутрівидових варіантів, зміни збудників в ході епізоотичного процесу і в результаті персистенції їх в тваринному організмі, внаслідок чого вони набувають видової специфічності (Bakulov and Tarshys, 1971; Atamas, 2008). 
Врахування екологічних принципів у вивченні взаємин між збудниками і об'єктами середовища дає змогу встановити два типи епізоотичного вогнища: природний i антропоургічний. Перший характеризується переважно трансмісивною передачею, другий наявністю циркуляції збудника, яка частіше передається аліментарним, аерогенним або контактним шляхами. Епізоотичні осередки склалися історично і здатні під впливом різних умов переходити від одного в інший - природний може стати антропоургічним i навпаки.

Міжвидові зв'язки в біоценозах, де циркулюють різні збудники, створюють умови для поширення хвороб внаслідок загальних місць локалізації, кормових зв'язків, загальних ектопаразитів, тому встановлення закономірностей в еколого-епізоотологічних зв'язках має вагоме значення. Найбільш повно розкриваються ці закономірності при збільшенні чисельності диких тварин - мишоподібні, білки, хом'яки, комахоїдні та ін., міграції ссавців і птахів, що сприяють поширенню ендо- та ектопаразитів і підвищують епізоотологічну активність членистоногих.

Деякі інфекційні хвороби людини і тварин з екологічних умов циркуляції збудника пов'язані з певними географічними зонами: степом, гірськими районами, тайгою, тундрою, пустелею, в яких постійно мешкають основні господарі збудника. При інших інфекційних хворобах кордони їх розповсюдження можуть виходити за межі дотичних або переходять ці зони.

В даний час відомо понад сто інфекційних хвороб, притаманних людині та тваринам (антропозоонози), які в різному географічному середовищі мають особливості як за ступенем розповсюдження, інтенсивності, сезонності, так і за частотою реєстрацій в окремі роки. Збудники антропозоонозів резервуються сільськогосподарськими тваринами, синантропними і дикими тваринами. Поширення збудника у зовнішньому середовищі відбувається передусім 3 виділеннями тварин, 3 тваринницькими продуктами і ектопаразитами.

Епізоотологічна географія, яка вивчає поширення заразних хвороб тварин в різних природньогеографічних умовах, дозволяє розкрити значення тих чи інших зовнішніх факторів. Крім того, за їі допомогою можна не тільки описати територію поширення тих чи інших інфекційних хвороб, але і пояснити географію захворювань, історію їх виникнення і розвитку. В результаті можна скласти прогностичні карти, за якими виявляють райони зі сприятливими i несприятливими умовами для поширення захворювань і дають прогнозування деяких епізоотій, що виявляються сезонно або через певну кількість років. Значна кількість інфекційних хвороб є антропозоонозами, а ареали їх розповсюдження пов'язані з фізикогеографічними зонами, в яких історично склалися природні осередки (Urban, 2001).

Шляхи переходу збудника від джерела до сприйнятливої тварини або людини залежать від екологоепізоотологічних зв'язків. Збудники хвороб, що входять до складу біоценозу природного вогнища екваторіальних країн, здатні адаптуватися в широтах континентального клімату, а збудники хвороб європейсь- ких країн мають генетичний зв'язок зі збудниками хвороб, що зустрічаються у країнах Далекого Сходу, Африки і Америки - енцефаліти, що передаються членистоногими і т. п.

Як приклад значення міжвидових епізоотичних зв'язків можна навести праці з акліматизації ондатри. Ондатра після завезення в нашу країну стала новим проміжним господарем ряду гельмінтів, а також носієм збудників деяких інфекційних хвороб - туляремії, лептоспірозу та ін. (Makarov, 2001; Horzheiev, 2013).

Найбільш істотними зовнішніми факторами, які зумовлюють коливання чисельності гризунів, вважають харчові, кліматичні, біоценотичні (міжвидова конкуренція, паразитизм, хижацтво), інфекційні та інвазійні хвороби i, нарешті, діяльність людини, що спрямована на винищення шкідливих гризунів.

Багато видів хребетних тварин здійснюють переміщення на значну відстань. Причинами міграції $\epsilon$ різні фактори зовнішнього середовища: недоїдання, посуха, холод, настання статевої зрілості й т. п. Рухливість i міграція тварин - один 3 екологоепізоотологічних факторів, що сприяють широкому розповсюдженню збудників інфекційних захворювань у зовнішньому середовищі (Naumov, 1963; Urban et al., 2001).

Міграції тварин можна поділити на періодичні, що протікають в певні сезони року, і неперіодичні, великі переміщення, у роки так званої мишачої напасті, нальотів птахів і т. п. Для епізоотології мають значення неперіодичні міграції, відомі для багатьох видів мишей - польова миша, степова пеструшка, водяна полівка та ін. Багато видів тварин, сприйнятливі до туляремії, лептоспірозу, лістеріозу та інших хвороб (білки, зайці, водяні полівки, ондатри, лисиці), мають високу плодовитість, внаслідок чого щільність їх проживання періодично помітно зростає. Виникнення ензоотій $є$ взаємопов'язане із збільшенням щільності даної популяції на порівняно невеликій території.

Значення трансмісії, резервуару і патогенності кровосисних членистоногих визначається екологічними умовами проживання ектопаразитів в тому чи іншому географічному середовищі, адаптаційними можливостями та міжвидовими зв'язками, які носять переважно аліментарний характер. У різні роки і сезони активність членистоногих $є$ мінливою, що пов'язано з погодними умовами, фенологічними особливостями, а отже, і з сезонною діяльністю, зменшенням або збільшенням числа господарів (гризунів, комахоїних, їх хижаків), чисельність яких також змінюється сезонами і роками. Членистоногі здатні переносити збудників хвороб вірусного і рикетсіозного походження, бактеріозів, бацильозів і паразитарних хвороб.

Епізоотологічна активність багатьох видів членистоногих визначається комплексом екологічних факторів, які обумовлюють передачу збудників хвороб. Деякі автори вважають, що двокрилі комахи здатні передавати збудників хвороб за територіальною розповсюдженістю і за часом. Іксодові кліщі здатні зберігати збудників тривалий термін при незначному їх поширенні по території, блохи обумовлюють циркуляцію збудника в замкнутому осередку, істотно не 
розширюючи його межі (Dzhupina, 1991; Romanenko and Evdokimov, 2004).

Нагромаджені за останнє десятиліття дані змінюють наше уявлення про епізоотологічну активність комах, іксодових, аргасових і гамазових кліщів. Відомі дані про перенесення птахами іксодових кліщів, заражених збудниками інфекційних та інвазійних хвороб, на значні відстані та навіть за межі країни. В результаті цього, на нових територіях можуть несподівано створюватися природні осередки антропозоонозних хвороб, свіжі вогнища (Ку-лихоманки, туляремії та ін.).

Маршрути перельоту мігруючих птахів пов'язують західні та східні, північні й південні країни світу. Орнітологи встановили, що на озерах Полісся разом $з$ птахами Карпат зустрічаються представники пернатих Середземномор'я, Монголії, Китаю, Тібету і навіть Далекому Сходу.

В даний час більш чітко визначається роль перелітних птахів як можливих резервуарів збудників, щопереносяться членистоногими на теплокровних тварин, здатність їх транспортувати арбовіруси. Відомі приклади виділення арбовірусів 3 крові птахів і їх ектопаразитів, спійманих в Індії, після тривалого перельоту з районів Північних Гімалаїв, Аргентини (ластівки), Каліфорнії. Відомо також, що через Єгипет мігрує понад 200 видів різних птахів. Причому 22 види скидають навесні кліщів роду гіалома, що знаходять в північних країнах. У Кенії виявлені кліщі цього роду у птахів, які прилетіли з Свропи.

Несподівана поява нових природних вогнищ на раніше благополучних територіях має бути проаналізовано з урахуванням зазначених вище можливих чинників поширення збудників. Варто мати на увазі, що поява нових вогнищ антропозоонозів має відповідну сезонність: у Північній півкулі це пов'язано 3 весняним гніздуванням птахів, а в Південній - 3 поверненням перелітних птахів (Romanenko and Evdokimov, 2004).

Епізоотологія, вивчаючи екологічні взаємозв'язки тварин (міжвидові зв'язки, екологію притулків диких тварин, міграцій і т. п.), розкриває закономірності прогнозування епізоотій, з'ясування яких має суттєве значення для складання плану протиепізоотичних заходів. Раціональний план заходів, розроблений на основі обгрунтованого прогнозу, забезпечує його ефективність. Показниками епізоотичних прогнозів можуть бути - стаціонарність, сезонність, періодичність захворювань, терміни вірусоносійства тваринами, що перехворіли, тривалість імунітету після природного перехворювання або штучної імунізації, санітарний стан пасовищ, присадибних територій і тваринницьких приміщень, міграція диких тварин, птахів та ін. (Urban, 2001).

\section{Висновки}

У виникненні, розвитку і перебігу епізоотій часто не враховуються екологічні особливості як збудників інфекційних захворювань (стійкість у зовнішньому середовищі, діапазон, адаптації до різних видів тварин та ін.), так і переносників і резервуару збудників.

Для ліквідації природних епізоотичних вогнищ велике значення мають такі обставини:

- можливе передбачення виникнення епізоотій;

- раннє виявлення епізоотичного вогнища;

- визначення межі епізоотичного вогнища;

- проведення комплексних протиепізоотичних заходів, спрямованих на усунення джерела зараження;

- обеззаражування забруднених об'єктів зовнішнього середовища і підвищення стійкості тварин 3 використанням заходів, засобів, загальної та специфічної профілактики.

\section{Бібліографічні посилання}

Atamas, V.Ia. (2008). Suchasni problemy epizootolohii. Ahrarnyi visnyk Prychornomoria. zbirnyk naukovykh prats. 42(2), 4-7 (in Ukrainian).

Bakulov, I.A. (2001). Jepizootologija podaet signal «SOS». Veterinarnaja gazeta. 8 (in Russian).

Bakulov, I.A., Tarshys, M.H. (1971). Heohrafiia khvorob tvaryn zarubizhnykh krain. M., Kolos, 21 (in Ukrainian).

Bisiuk, I.Iu. (2012). Suchasnyi stan i problemy kontroliu transkordonnykh emerdzhentnykh infektsii tvaryn $\mathrm{v}$ Ukraini ta sviti. Zh. Veterynarna medytsyna. 96, 11-14 (in Ukrainian).

Horzheiev, V. (2013). Epizootychna sytuatsiia v sviti ta yii vplyv na protyepizootychni zakhody $\mathrm{v}$ Ukraini. Zdorovia tvaryn ta liky. 12(145), 8-11 (in Ukrainian).

Dzhupina, S.I. (2001). Jepizootologija podaet signal «SOS». Veterinarnaja gazeta. 9 (in Russian).

Dzhupina, S.I. (1991). Metody epizootologicheskogo issledovanija i teorija epizooticheskogo processa. Novosibirsk: Nauka. Sib. otdelenie, 39-41 (in Russian).

Makarov, V.V. (2001). «Diskussija» o problemah jepizootologii. Veterinarnaja gazeta, 9 (in Russian).

Naumov, N.P. (1963). Ekologija zhivotnyh. M.: 2 izd. (in Russian).

Pljashhenko, S.I., Sidorov, V.T. (1978). Estestvennaja rezistentnost' organizma zhivotnyh. L.: Kolos (in Russian).

Romanenko, N.A., Evdokimov, V.V. (2004). Problemnye territorii i parazitologicheskie bolezni. M. (in Russian).

Urban, V.P., Sochnev, V.V., Makarov, V.V., Dzhupina, S.I. (2001). O problemah jepizootologii. Veterinarnaja gazeta. 4 (in Russian).

Urban, V.P. (2001). Jepizootologija i jepidemiologija trebujut razvitija i sblizhenija. Veterinarnaja gazeta. 10 (in Russian). 